\title{
$\mathrm{XV}$ 。シェーグレン症候群
}

1. シェーグレン症候群における血中免疫複合体の検 索とその臨床的意義について

東医歯大第一内科
西戸 孝昭, 宮坂 信之
川満 久恵, 奥田 正治

目的 : Sjögren 症候群 $(\mathrm{SjS})$ 血清中の免疫複合体 (IC) の存在は，これに起因する堅炎，血管炎の発症など本症 の二次的病変拡大ならびに予後に重要な意義を有すると 考兵られる. かかる観点から我々は自験 SiS 症例39例 の血清 IC を検索し，䠛床病像，血清学的所見などとの 関連性について検討した。

方法 : 被検血清は分離後直ちに $-20^{\circ} \mathrm{C}$ に保存, 検查 直前に解凍し，16倍および64倍稀视血清について，矢田 らの方法に従い， Raji cell assay により IC の測定を 行なった. また一部症例には Clq-binding RI assay を 試及対比した。

結果と考察：(1) 16 倍血清に打ける IC 陽性率は $56 \%$ で, RA 12 例の同陽性率 $58 \%$ とほぼ同率であった. (2) sicca alone 症例（22例）の陽性率は 45\%とや小低值て あったが，各病型間の有意差は認めなかった。(3)椧查所 見のうち, 血沈 $(20 \mathrm{~mm}$ 以上 ; $\mathbf{p}<0.05)$, 高 $\gamma$-glob 血 症 $(1.5 \mathrm{~g}$ 以上 ; $\mathrm{P}<0.025)$, リゥマチ因子陽性 $(\mathrm{p}<0$. 005）と有意の相関を示し，また sicca alone 群では， リウマチ因子陽性 $(\mathrm{p}<0.01)$ および advanced sialogram $(p<0.025)$ と相関を示した. (4) IC titer 高值 (64倍) の症例は23\%で，このうち sicca alone は1例のみであ った. Raji cell および RI assay の対比では, 前者の 陽性率がや〉高く，両者一致率は76\%であった。

以上， SjS 血清中の $\mathrm{IC}$ 陽性率は $50 \%$ 以上であり，高 titer は CTD 合併例， CTD-like の症状を伴う例お 上 び腎炎合併例に高率にみられ SjS の病変の拡大との関 連が強く示唆された。

\section{2. シェーグレン症候群の診断と酸性核蛋白抗体} 磨大内科

山県 元, 岡本 尚
東條 毅, 本間 光夫

目的 : シェーグレン症候群 $(\mathrm{SjS})$ では, 酸性核蛋白 抗体の陽性率が高いが，疾患特異性の認められたものは
SS-A，SS-B 抗体である. そこで両抗体の臨床的意義を 求めた.

方法 : 各種酸性核蛋白抗体を梌索しえたリウマチ性疾患 を対像とした．各例の初回抗体検索時の臨床諸所見に厚 生省 $\mathrm{SjS}$ 基準を適用し，診断しえなかった症例を分類 した.これより SS-A， SS-B 抗体陽性例を抽出し，陰 性例と対比しつつ，経過中に SjS 診断に至った例を検 討した，つぎに最終観察時点での SjS 確診例につき， 抗体の䅅過による変動と特異臨床所見との関連をみた。 抗体は二重免疫，拡散法により標準血清を用いて同定し た. 抗原は幼若家鬼胸腺，ヒ上肝生食可溶画分を用い た.

成績：1）抗体初回梌索時に SjS と診断しえなかった が両抗体のいずれか陽性の例は85例であった.この群の 最終観察時までの経過を抗体陰性群と比較した結果, 特 徵的䔩燥症状を認めた例の頻度, $\mathrm{SjS}$ 基準を满足するに 至った例の頻度は共に高率であった。

2) 最終観察時の確診 $\mathrm{SjS}$ は 48 例となった. 2 年以上 観察の30例では両抗体の持続陽性例が多く, 発熱, 耳下 腺腫脹反復の 2 例でむ抗体価は 5 年以上不変であった.

結論 : SjS に批石 SS-A, SS-B 抗体は早期上り出 現し，持続陽性を示すことが多かったので，その検出 は, $\mathrm{SjS}$ 早期補助診断法として有用之思われる.

3. Sjögren 症候群の病型と自己抗体に関する検討 名保衛大内科

鈴木 定, 浜本 龍生, 宮地 清光 杉浦 元孝, 鳥飼 勝隆, 梅田 博道 同中検

前野 芳正

目的 : Sjögren 症候群 $(\mathrm{SjS})$ に比較的特異的とされる SS-A, SS-B 抗体の臨床的意義を明らかにする目的で， SjS の各病型和よび他の結合織疾患における頻度と臨床 像を椧討した。

方法：対象は SjS 27. SLE 26, RA 16，その他の結合 織疾患13，正常人 54例である. SS-A 抗原はヒト肝より 抽出L，SS-B，Sm，n-RNP， $r$-RNP，は幼若家鬼胸腺粉 末を用いた. SS-A， SS-B 抗体の同定は各種標準血清を 対照とし， $0.6 \%$ アガロース内での二重免疫拡散法にお 
ける沈降反応の一致によった.

成績およひ考按 : SS-A 抗体は SjS で70\%特に Sicca alone では89\%が陽性であり，他の結合織疾患ではSLE の31\%以外は全て低率あった．また Sicca alone では 高扰体価の傾向がみられた. SS-B 抗体は Sicca alone で $83 \% \mathrm{SjS}+\mathrm{RA}$ で $11 \%$ に陽性であり，その他の症例 では全く陰性で Sicca alone K極めて特異性が高かっ た. 以上の結果より SjS を SS-A, SS-B 陽性群, SS-A 陽性 SS-B 陰性群, SS-A, SS-B 陰性群の 3 群に分類し 臨床症状，耳下腺造影に批ける Stage 分類を比较した が特に有意の差は認められなかった，臨床的に乾燥症状 を認めないSS·A 暒性のSLEについて，眼科学的検查 および Sialography を施行したが $5 / 8$ に何らかの異常 を認めた，しかしながら残り 3 例については，今回の検 索では SjS の合併怕否定的であった. Sialography K ついては SjS 以外の結合織疾忠にも陽性所見を示すと の報告があり，今後さらに SjS の病型と SS-A SS-B 抗 体との関倸について経時的に愉討を加える予定である.

\section{4. シェーグレン症候群と内分浠系自己免疫疾患} 神大第三内科

岸原 道三, 中尾 実信, 馬場 泰人
山内 㻖平, 田港 朝彦, 松倉 茂
藤田 拓男

神戸中央市民病院内科

$$
\text { 森徹 }
$$

系統的自己免疫疾患であるシェーグレン症候群には従 来上り種々の自己免疫疾患の合併することが知られてい る. 今回我々は，その内特に藏器特異性の比輅的強い内 分歩系自己免疫珄甲状腺疾患である橋本病およびバセド ウ病を合併した 2 症例を経験した，しかる前者はその血 中心 $T_{8}$ 自己抗体を缌め, 後者は最近その病因として TSH 受容体抗体が注目されている為, 若干の免度学的 倹討を加えた（症例 1) 39才女性, 口内翰燥感, 顔面 下駺浮腫を主訴として来院した，甲状腺機能検査は， $\mathrm{T}_{4}$ $1.8 \mu \mathrm{g} / \mathrm{dl}, \mathrm{T}_{3}$ Ong $/ \mathrm{ml}, \mathrm{T}_{3}$ RSU $9.4 \%$, TSH $150 \mu \mathrm{u} /$ $\mathrm{ml}$, BMR-22\%であり，針生検にて橋本病による甲状腺 機能低下症の合併が示唆された。 しかも $\mathrm{T}_{3}$ ならびに $\mathrm{T}_{3}$ RSUが異常低値を示したことより，血清のエタノール 抽出を行った所, 多量の $\mathrm{T}_{8}$ が㛟出され， $\mathrm{T}_{8}$ 自己抗体の 存在する可能性が示唆された，従って本症血清と ${ }^{225 I-T_{3}}$ の結合を Gel Chromatography により倹討すると; 対
照群では 4S 分画 (TBG 分画) にその放射舕性を認め たが、本症では $7 \mathrm{~S}$ 分画にのみ認めた. しかもその結 合は IgG 分画を用いてむ同様敒恋められ，Scatchard 分析により親和定数 $1.5 \times 10^{11} \mathrm{M}^{-1}, \mathrm{~T}_{3}$ 結合能 $0.27 \mu \mathrm{g} /$ $100 \mathrm{ml}-$ Serum ときわめて affinity の高い $T_{8}$ 自己抗体 の存在が示唆された.（症例 2) 46才女性, “動悸, 涙液 分沁低下を主訴として来院した：種々の甲状腺機能検査 ならびに甲状腺針生㭘にてバセドゥ病の合併が示唆され た. しかも TSH の Radioreceptor Assay を用いるこ とにより，本症血中には標識 TSH の TSH receptor への結合を抑制する免度グロブリンの存在が 示唆され た.

5. Sjögren 症候群患者末梢白血球の ADCC (Antibody-Dependent Cell-Mediated Cytotoxicity) 活性 と赤血球会食反応

\section{東海大内科}

市川 幸延, 高屋 正敏, 有森 茂

目的 : Sjögren 症候群 $(\mathrm{SjS})$ 患者末梢白血球の ADCC ならびに赤血球貪食活性を検討した.

方法: 攻撃細胞としてヘパリン加血より, FicollConray 比重遠心法にて crude lymphocyte fraction (CLF)をまた carbonyl ironを用いて phagocyte を除去したのち比重遠心法にて phagocyte depleted fraction (PDF) を分離した，標的細胞として ${ }^{31} \mathrm{Cr}$ 標 識, ウサギ抗ヒッジ赤血球抗体結合ヒッジ赤血球を使用 した. ADCC 活性は PDF と標的赤血球を 20 時間培盖 した上清中の放射活性を，赤血球領食活性は CLF を攻 撃細胞としたさいの細胞内放射活性を示標とした。

成績: SjS 患者の ADCC 活性は健常人とくらべて低 值を示す症例が一部にみられたが，全症例 (14例) の平

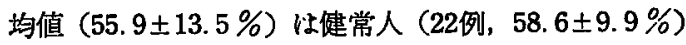
との間に有意差は認められなかった，ADCC 活性の低値 と, 他の自己免疫性疾患の合併の有無, 末梢りンパ球

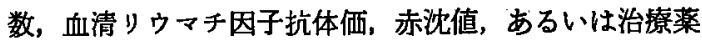
剤との間に関連は認められなかった，CLF における Fc レセブター (FCR) を介する赤血球貣食活性は $\mathrm{SjS}(17$. $9 \pm 9.4 \%)$ て健常人 $(37.2 \pm 10.6 \%)$ とくらべ著しい低 値を示した. 一方，FCR を介さない赤血球貪食活性は $\mathrm{SjS}(20.3 \pm 6.6 \%)$ と健常人 $(21.9 \pm 6.8 \%)$ との間に 差を認めなかった。

$\because$ 結論 : SjS では末梢りンパ球の ADCC 活性の低下し ている症例が一部に存在し，さらに単球に由来する FcR 
を介した赤血球食食活性の低下が認められた。

6. Sjögren 症候群における抗リンパ球抗体につい $\tau$

\section{埼玉医大第二内科}

関谷進一郎, 川口 卓治, 石橋 俊子

松尾寛, 鈴木 輝彦

目的：抗リンパ球抗体はSLE で高率にみられ，その 発症機序への関与が考えられている. 又 Sjögren 症候 群 (SjS) は多彩な免度現象を示寸ばかりでなく，他の 膠原病を合併する症例も多い，そのため郖床症状および 険查成績から 幾つかの病型に分類され得ることが従来 より指摘されて扣り，我タは以前より(1)Sicca alone 群, (2)Sicca+CTD like, (3)Sicca+overlap の 3 群に分けて 来た. 今回この 3 群の抗リンパ球抗体について浼討した ので報告する．

対象および方法 : 対象はSjS 35 例. その内訳は Sicca alone 12 例, Sicca +CTD like 11 例, Sicca + overlap 12例. 正常人20例, SLE 20 例, RA 20 例を対照群とし た. 方法は $15^{\circ} \mathrm{C}$ の条件下で Terasaki らの方法に準 じ，死細胞率20\%以上で陽性とした。

結果 : (1)SjS 全体では35例中12例 (34\%) 飞陽性であ った。対照としたSLE では20例中16例（80\%)，RAで は20例中 2 例 $(10 \%)$ に陽性であった. な扣正常人では 全例陰性であった. (2)SjS 病型分類では, 細胞性免挖が もっとも低下している Sicca alone 群では，予想に反 し 12 例中陽性例はなく，CTD-like 群では 11 例中 5 例 $(45 \%)$, overlap 群では予想に反し12例中 7例 $(59 \%)$ が陽性であった.

7. 腎尿細管性アシドーシスを伴ったシェーグレン症 候群の一家系

\section{東大物療内科}

山本 一彦, 赤塚 俊隆, 児玉 龍彦 茄原 忠夫，行山 易志，加賀美年秀

堀内 淑彦

Sjögren 症候群に腎尿細管性フシドーシスを合併し， 多彩な臨床症状と免度学的異常を呈する稀有なる家系を 検索中であるが，現在までの結果を報告した，発見の端 緒となった姉妹 2 症例; 妹は多飲多尿, 四肢脱力感を伴 った18才女性，口唇生検，シアログラフィーより Sjögren 症候群と診断, また塩化アンモニウム負荷試識験及びピ トレッシン不応の浱縮力障害より，遠位尿細管性フシド
ーシスと詠断した，腎生検では，間質に口唇生検所見之 類似した極めて著明なリンパ球，形貿細胞の浸潤を認め た. 林は多领, 口渴, 紗り返す耳下腺腫脹, 関節痛を主 訴とし，妹と同様に Sjögren 症候群と尿細管性アシド ーシスと診断した．以上の症例に引き継いで，親族13名 を調査したが，母親に口渴，演縮力障害，低K血症，低 尿酸血症を認め，同一疾患の叮能性浱厚なるを始め，同 胞，父方親族に抗核抗体陽性，低 $\mathrm{K}$ 血症，アシドーシス を示寸例が多い，近隣者 2 人にも同様に抗核抗体陽性， 低K血症が認められた。この家系及び近隣者にすSjögren 症候群を中心とする自己免疫疾患の存在が強く われることは、これらの原因が単に遣公因子だけでな く，水その他の環境污染，ウイルスなどの環境因子に求 められる可能性のあることを示陵している. 今後さらに 調查の幅を広げ，HLA を中心とする溃伝学的検查， SS-A, SS-B 抗体の倹索, ならびにウイルスを中心とす る環境因子の分析を行っていく予定である.

8. シェーグレン症候群における堅組織所見に関する 検討

川崎市立川崎病院内科

入交昭一郎, 美田 誠二, 河野 通律
松岡 康夫, 東 冬彦, 藤森 一平
同 病理
福田 純也

目的 : Sjögren 症候群に和ける腎組織像について塆液 腺組織像执よび免疫血清学的検查成績との関係を検索 しささらに尿細管アシドーシス（RTA）についても桧 討することを目的とした.

対象および方法 : 厚生省シェーグレン病調查研究班の 猃断基準を满足する definite Sjögren 症候群 15 例㷂 生検を施行し，唾液腺は主として口唇生検によってその 組織像を娭討した，RTA の検索は塩化フンモン負荷試 験ならびにダイアモックス負荷試験によって行った.

成績および結論：対象とした15例は全例臨床的に堅症 のない症例ですべて女性であった.

堅組織像では，糸球体には種々の变化が認められた が，尿細管周囲間質に明らかな細胞漫潤を認めた例は 6 例で，浸潤細胞は主としてリンパ球であった。堅組織所 見とくに尿細管周囲の細胞浸潤之䀣液腺組織所見とは必 ずしも一致しなかったまた細胞浸潤の有無，程度と免 疫血清学的検查成績との間にも特徵的なつながりは見出 せなかった。 
RTA の存在を認めた 2 症例の内 1 例は免疫血清学的 に多彩な自己抗体を証明し，唾液腺および尿細管周囲間 質に高度の細胞浸潤を示す sicca syndrome alone の例 であったが，他の1例では腎尿細管周团の組胞浸潤は軽 度であり，腎組織像より RTA の存在を推測すること は困難と考えられた。

9. シェグレン病における血清および塆夜中の $\beta^{2}$ microglobulin $の$ 定量

自治医大耳科

木村 徹男, 小松崎安美, 森田 守

同 臨床病理

金衡仁

1975年 Talal, Michalski らはシェグレン病患者の血 清および唾液中の $\beta_{2}$-microglobulin (以下 $\beta_{2} \mathrm{~m}$ と略す) 瀑度が著明に上昇し，また症状の消長に一致して変動す ることを報告した，このたび我々は唾液腺疾腎64例（シ ニグレン病13例, シェグレン病の疑い 8 侧, シェグレン 病を否定できる口内乾燥感あるいは舌炎患者29例，放射 線治療後の险液分泌低下 4 例（いずれも咽頭悪性属湯）, およびその他の活液腺疾患10例）につき安静無刺激時の 混合隹液と血清中の $\beta_{2} \mathrm{~m}$ 濃度を radioimminoassay 法 を用いて測定し，さらに唾影像および口唇腺組織像と対 比し, 以下の結果を得た。

シェグレン確定群で $\beta_{2} \mathrm{~m}$ 濃度は血清中 $2.75 \pm 1.38$ ，

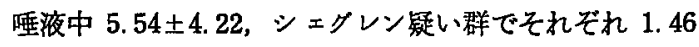
$\pm 0.38,2.41 \pm 1.14$, 口内乾燥, 舌炎群で1.77, 2.22 1.64, 放射線治㞠後の唾液分泌低下群で $2.92 \pm 1.43$,

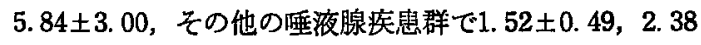
\pm 2.08 とシェグレン病確診群, 照射群で $\beta_{2} \mathrm{~m}$ は血清, 唾液の両方とも, シェグレン病疑診例では唾液のみが他 の群に比し，有意に高值を示した。また唾影像および棰 液腺組織の病変が高值のもの程, 哽液中 $\beta_{2} \mathrm{~m}$ 值も高い 傾向を示し、これがシェグレ病群の涶液中 $\beta_{2} \mathrm{~m}$ 值の症 例間の差が大きい主因と思われたが，このことより喠液
腺病変の程度を推定する定量的訅断の意義が 示娔され た. また唾液中 $\beta_{2} \mathrm{~m}$ はステロイドの投与によりすみゃ かに変動することより，治療効果の判定にも有用なこと が示崚された。

10. シェーグレン症候群の既往歴

一女性生殖器患疾患との関係について— 岡山大第三内科

$$
\begin{aligned}
& \text { 景山ケイコ, 小豆沢秀夫 } \\
& \text { 宮脇 昌二, 大藤 真 }
\end{aligned}
$$

シェーグレノ症候群 (以下 $\mathrm{SjS}$ ) の既往歴, 合併症に 多数例の螮人科在患があることを第 5 回本学会で報告し た. その後さらに症例数を增して両者の関係觉検討し， また婦人科疾患の側から SjS の存在を調查した。すず SjS 腎者女性例136例の既往歴，合併症を調べた．136例 の内訳は厚生省 SjS 班診断基準をみたす SjS 確実例が 109例, SjS 疑い例が27例であった. SjS 確実例109例中 39 例 $(35.8 \%), \mathrm{SjS}$ 疑い例 27 例中 9 例 $(33.3 \%)$ k子 宮筋腫, 即巣のう腫等の婦人科疾患の既往または合併 を認めた．これは当科慢性関節りウマチ患者における婦 人科疾患既往歴, 合併率の $12.2 \%$ ，全身性エリテマトー デス患者の $0 \%$ ，橋本病の $10.6 \% ， 一$ 般疾患患者の 8.4 \%に比へ高率であった．SjS 忠者で合併した婦人科疾患 の内訳は，子宮筋腫 23 例，子宮癌 1 例，卵畨の5隀 11 例, 卵巣機能低下症 7 例, 女性生殖器付属器炎 3 例, 乳 腫症 2 例，乳癌 1 例であった.つぎに婦人科受診患者73 例に乾燥症状の問猃，淡，唾液腫分泌機能倹查，小唾液 腺生検を施行し SiS の存在の有無を涣索した．その結 果 $40 / 73(54.8 \%)$ 飞乾燥症状を, $37 / 61(60.7 \%)$ に 涙分泌機能異常を，また $21 / 52(40.4 \%)$ に唾液分泌機 能異常を認めた。しかし小㕰液腺生検像は施行しえた40 例の内 9 例 $(22.5 \%)$ が異常を示し陽性率は比較的低率 であったが，子宮杵腫にて子宮ならびに卵巣摘出術を受 けた群に高率に陽性であった．以上，Sj と婦人科疾患 の間には何らかの因果関係があることが示唆された. 